\title{
Transfer of toxic substances from feed to food
}

\author{
Cornelis Adriaan Kan ${ }^{1}$ \\ ${ }^{1}$ Formerly at the Animal Sciences Group of Wageningen University and Research Centre, Lelystad, The Netherlands.
}

\begin{abstract}
The title may raise questions about definitions of the terms used. The more obvious ones are: 1) What is transfer? 2) How to define toxic; and 3) How to define feed or food. A more underlying question is how to measure the substances we are interested in. The (often) chemical methods used, are not always sensitive or specific enough. Sometimes, biologically based methods are used which detect a biological response, but seldom identify the compound responsible for that. Transfer is often not quantified in absolute terms but expressed in concentrations in feed and food. Mass balance between intake and excretion are quite rare as a steady state situation of residues in the animal is sometimes not obtained. Toxicity is mostly dependent on the concentration of the substance involved and even substances presumed to be innocent. Feed does certainly include the materials provided to the animal but also include the soil in which they walk and graze? Animals will consume some of the soil and it might contain considerable amounts of unwanted substances. Food certainly includes meat, milk and eggs and probably liver and kidney. But does also include intestine, spleen, testicles or even bone? Analytical methods may give wrong results if not applied properly and with adequate background knowledge. The recent episode of melamine in milk powder has been a very tragic wake-up call in this respect. Based on 35 years of carry-over studies with farm animals and data from the literature, a number of these points will be discussed.
\end{abstract}

Key Words: carry-over, feed, food, risks, toxic substances, transfer

\section{Transferência de substâncias tóxicas de alimentos para animais para alimentos para humanos}

RESUMO - O título deste artigo pode levantar algumas questões a respeito dos termos adotados. As mais óbvias são: 1) O que é transferência? 2) Como definir tóxico? 3) Como definir alimento para animais e para humanos? Uma questão mais destacada é como medir as substâncias nas quais nós estamos interessados. Os métodos químicos frequentemente usados, nem sempre apresentam sensibilidade ou são suficientemente específicos para os metabólitos que desejamos. Algumas vezes, métodos com base biológica são usados, os quais detectam uma resposta biológica, mas não a identidade da substância responsável pela resposta. Transferência frequentemente não é quantificada em termos absolutos, mas expressa em concentração no alimento. Os balanços de massa entre ingestão e excreção são raros, e assim as condições de estabilização dos resíduos no animal muitas vezes não são obtidas. A toxicidade é dependente principalmente da concentração da substância envolvida e até mesmo da concentração da substância presumida como não tóxica. Entre os alimentos fornecidos aos animais pelo produtor se inclui outros materiais, como solo por exemplo. Animais que consomem solo podem ingerir quantidades consideráveis de substâncias não desejáveis. Alimentos para humanos certamente incluem carne, leite e ovos, e provavelmente fígado e rins. Mas incluem também intestino, pulmão, testículos, ou mesmo osso? Os métodos analíticos podem dar resultados errados se não aplicados corretamente e com conhecimento. O recente episódio da melamina no leite em pó foi uma trágica ocorrência que reforça a atenção dos pesquisadores. Baseado em nossos estudos de mais de 35 anos sobre contaminação cruzada e de dados de literatura, vários destes pontos destacados serão discutidos.

Palavras-chave: alimento para animais, alimento para humanos, contaminação cruzada, substâncias tóxicas, transferência

\section{Introduction}

Carry-over or transfer of toxic substances - e.g. pesticides, heavy metals, veterinary drugs, environmental contaminants and mycotoxins - from feed to food is a well known phenomenon (Kan \& Meijer, 2007). A definition of the different aspects involved in this process is often not given and it may help to avoid misunderstandings or controversies when discussing the results observed in incidents in this field.

Transfer is often not quantified in terms of absolute amounts or percentage of daily intake. There are a number of reasons for this fact; a main one is that the legislation all over the world is purely based on maximum allowable concentrations in feed and food. Thus quantitative relationships (if possible to establish) are not of major 
interest to policymakers, so no pressing questions are asked to the scientists and no funds made available for this type of research. Secondly, only in lactating or egg laying animals a quantitative relationship between intake and excretion in edible products can be rather easily obtained. In meat-producing (growing) animals deposition of toxic substances in edible products is much harder to establish and adequate sampling and analysis of the excreta for the toxic substance studied is often not feasible. In laying hens we have measured excretion rates via eggs of some chlorinated pesticides of about $80 \%$ of daily intake (Kan, 1977). The excretion of sulfadimidin via the egg - although clearly detectable in the eggs after exposure - was on the other hand below $1 \%$ of the dose (Geertsma et al., 1987).

Toxicity of a substance is dependent on the exposure level. This implies that substances presumed to be innocent, can be harmful at high concentrations as well as that substances known to pose a health risk at high concentrations, can be present at such low concentrations or in such (chemical) form that no increased health risks are present. So on the one hand, vitamins are essential in the nutrition of both animals and man, but excess Vitamin A amounts in broiler feed (to obtain white coloured broiler meat) do lead to high vitamin A levels in liver, which may pose a treat to human health if liver is a major part of an unbalanced diet. On the other hand the levels of heavy metals currently observed in animal diets, have not been shown to be detrimental to animal health or performance. Carcinogenicity however is probably not dependent on level of exposure. One molecule of a genotoxic compound might be sufficient to induce the mutation leading to cancer. This cancer incidence might - however - be so low, that it does not increase the risks above existing background cancer levels. The quite common belief that manmade chemicals are much more dangerous than molecules made by nature is not true. Botulinum toxin (produced by certain Clostridium bacteria) is among the most acute toxic substances and aflatoxin (produced by the fungus Aspergillus) among the strongest carcinogens.

Feed, water soil and air - soil contamination and probably soil intake by the animal is a major factor in dioxin contamination of eggs from free range hens (Kan, 2007). Soil intake by cattle and especially sheep (due to their short grazing) is well known, but laying hens were (much to our surprise) able to ingest as much as $30 \%$ sand in their diet without noticeable effects on egg production (van der Meulen et al., 2008). Surface water might well be contaminated as well as air in some areas. Their contribution to the total exposure of animals is unfortunately not yet quantified.

Edible products - the lipophilic compounds such as organochlorine pesticides and dioxins will accumulate in the fat and the fatty portions of the animal products. Thus lean meat and defatted milk will contain low levels. Heavy metals will accumulate in liver and kidney. Other organs have often not considered as being important and legal limits have not been set for them. Mycotoxins and veterinary drugs may also occur in protein rich products such as milk and eggs, but no general picture does emerge from the available data.

Analytical methods to detect the presence (or absence) of toxic substances are the basis for all data and conclusions to be drawn from them. Mostly these methods are well developed and executed. Biological methods such as the CALUX bioassay to detect dioxins have their merits as a screening method (Hoogenboom et al., 2004) but do not generally prove the identity of the substance giving the response. All methods thus have their limitations and these are not always understood by the layman using the results. The recent episode of melamine in milk powder being undetected as such, but assumed to be protein was a very tragic wake-up call. Another example might be the use PCB's in feed related incidents as marker for the presence of dioxins, as the PCB analysis is much simpler and cheaper than the dioxin one. The EU authorities used a ratio of 50.000 between indicator PCB's and dioxins in the Belgian dioxin crisis in 1999 (Hoogenboom et al., 2004). Our results showed that during passage in broilers and pigs this ratio was more or less constant and thus very useful. However during the dioxin incident in milk in the Netherlands in 2004, where kaolinic clay was the dioxin source, no PCB's were present (Hoogenboom et al., 2005) thus such an approach would have led to false negative results. Some substances are (almost) completely metabolised during passage of the animal and thus the parent compound is not detected but metabolites (sometimes with an unknown toxicological profile) might well be present. We exposed laying hens to nicotine to look for potential adverse effects on the hens and residues in the eggs (Hoogenboom, Traag and Kan unpublished results, 2005). The parent compound was not detected in the eggs, but at least two metabolites (cotinin and 3-hydroxycotinin) were recovered from the eggs. Thus the analytical method used and the results reported should not be confined to the parent compound, but should also include at least these two metabolites to produce a meaningful answer to the question, whether or not exposure 
had taken place and if any health risks would be connected to those eggs.

The judgement whether or not transfer of toxic substances from feed to food poses a threat to human health thus requires considerable background knowledge to arrive at the right conclusion.

Toxic effects - in reality, the acute and semi-acute adverse health effects in man due to toxic substances from animal derived food have been quite limited during the last 35 years. To my knowledge only two examples are reported; the first concerned polybrominated biphenyl residues in the US during the mid 1970s during to (erroneous) inclusion of a flame retardant in dairy feed (Who, 1994). The second (involving several episodes in several countries e.g. Barbosa et al. (2005) are â agonist (mainly clenbuterol) residues in liver causing heart problems in quite a number of consumers. In all instances, these residues were caused by illegal use by farmers to increase muscle mass and reduce fat content in meat type animals.

Transfer or carry-over - Most components of animal feed are digested as well as absorbed during passage through the intestinal tract. Animal nutrition focuses on those components, which have a nutritive or positive value for the animal. Digestion and absorption of nutritive components have been extensively studied. In contrast, for toxic - unwanted - substances like dioxins, mycotoxins, heavy metals, pesticides, veterinary drugs and polycyclic aromatic hydrocarbons, although often analysed in both feed and animal product, digestion and absorption in the animal, is often not considered. Some scientists assume complete absorption of these noxious substances, as a worst case scenario to predict residues in animal products from those in feed. This approach does not take advantage of existing knowledge to identify or implement possible control points for reducing residues in animal products.

Toxico-kinetic data with emphasis for the physiological processes occurring in the animals should be the key focus point of the discussion, in order to allow meaningful predictions for situations not directly covered by existing data. The review by Kan \& Meijer (2007) focuses on data published during the last 10 to 15 years. Good reviews for older data are available and some older data might have become obsolete due to much lower exposure levels and much improved analytical and toxicological methodology.

Chlorinated pesticides and environmental contaminants - The data on carry-over percentage (amount excreted per day via milk or eggs or deposited in the animal/ amount ingested per day) or concentration ratio (concentration in product/concentration in feed) as well as half life of these compounds (if reported or to be deduced) are summarized by Kan \& Meijer (2007). The majority of the data are on milk and eggs, as changes in residue contents in the product during the exposure to the contaminant, are easily measured in these products. Construction of a time related residue profile in meat type animals requires either sequential slaughtering or frequent sampling by tissue biopsies. Interpretation of these curves - if available - is not very easy and is further hampered by dilution to growth and changes in body composition during growth.

Overall, the compounds can be divided in three major classes; 1 ) the compounds rapidly metabolized and excreted, one example being chlorpyrifos, 2) compounds with detectable accumulation in the animal, one example being lindane and 3) compounds with high accumulation in the animal, examples being DDT and dioxins. Kinetic models are essential in making reliable predictions of residues to be expected from a limited data set. This situation often occurs during a crisis with contaminants in feed or the environment. Van Eijkeren et al. (2006) have recently described such a kinetic model for dioxins and PCB's in laying hens. The problems with dioxins in a potato by-product fed to dairy cows, was one example were a kinetic model was successfully used to predict residue levels in milk after cessation of feeding the product (Hoogenboom et al., 2005). Figure 1 shows the excellent correlation between predicted

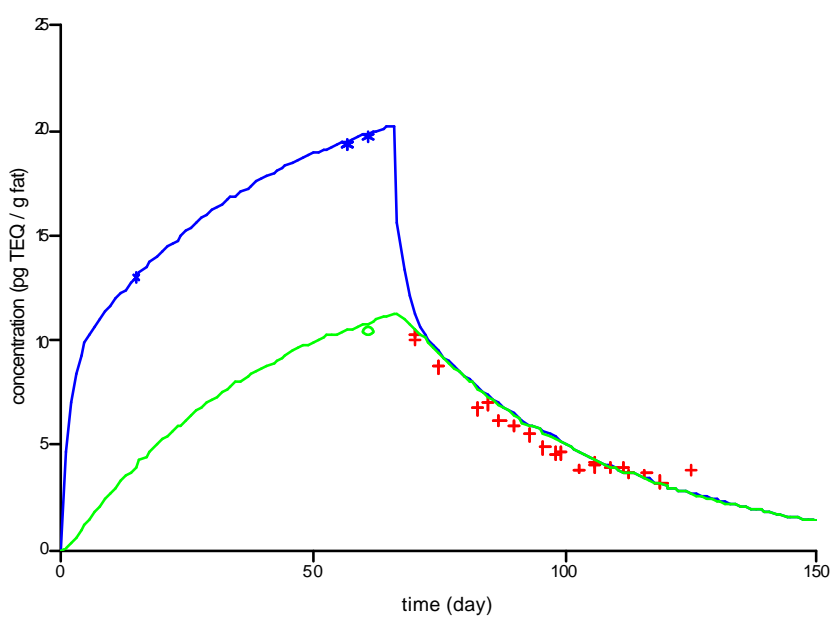

Figure 1 - A standard PBPK model describing the kinetics of dioxin in the cow was calibrated on three concentration in milk data during the phase of contamination $(*)$ by fitting the starting day of feeding contaminated peelings. The model was used to calculate levels in milk fat (upper line) and body fat (lower line) and compared to data in milk fat $(+)$ taken after cessation of the contamination and one body fat sample (o). 
residue concentrations in the milk and those observed during the withdrawal period.

Risk management of chlorinated pesticides and environmental contaminants - cessation of direct application on animals or presence of persistent compounds in their feed, houses or meadows is -of course- the first measure to control residues. Prevention of occurrence of residues in products of animal origin (a control point in HACCP) can be done via control of levels in (fat containing) feedstuffs. This approach has proven its efficacy in reducing residue levels over the past 30 years (e.g. Kan, 2004). Residues of contaminants in products of animal origin due to environmental contamination are harder to be controlled (Kan, 2005). When (legally) acceptable limits for residues have been surpassed, removal of the contaminated items from the human food chain is the only option. The direct and indirect costs involved in these recall and removal operations are often quite substantial.

Heavy metals - An important feature of heavy metals is that the chemical form in which they are present may change during passage of the intestine or storage in animal tissue, but that they are not metabolized. The studies by Vreman et al. (1986) and Kreuzer et al. (1981) clearly showed that muscle and milk are not likely to show high levels of heavy metals when animals are exposed via the diet. Liver and kidney - on the other hand - often show a clear doseresponse related increase in heavy metal concentration after dietary exposure.

Risks and risk management - the HACCP approach suggests the following: Reduction of exposure via feed is relatively easy by avoiding the use of certain contaminated feedstuffs. However, environmental and incidental exposure is hard to control. Checks on levels of heavy metals in animal products are generally executed on a survey basis and prevention of occurrence of products with violative levels of heavy metals seldom or never occurs (Kan, 2002).

Mycotoxins - Mycotoxins in feed and their transfer to foodstuffs of animal origin as well as the strategies to prevent occurrence of adverse effects have been discussed at length in numerous reviews in textbooks and journals.

Risk management - prevention and control of mycotoxins in the pig and poultry production chain have been described by Dänicke et al. (2000, 2002). Emphasis was laid on prevention during the growing phase of the plants, as removal or inactivation of the toxins often proved to be quite difficult or not economical. Mycotoxin control in the field is - however - quite hard to be executed. Weather conditions play a pivotal role in fungal growth and mycotoxin formation, and can not be controlled. Galvano et al. (2001) have concentrated on dietary strategies to counteract the effects of mycotoxins. However the economical and technical feasibility has still to be established for many suggested strategies, as efficacy under practical conditions is seldom measured or reported.

Diaz and Smith (2005) concentrated on sequestering agents to counteract the effect of mycotoxins. Some promising products are described in their contribution. They stress - however - thatin vitro tests on binding may not be good predictors for in vivo efficacy. They further warn for generalizations concerning efficacy comparisons between types of animals or mycotoxins.

Veterinary drugs and feed additives - Veterinary drugs and feed additives are generally administered to animals on purpose and an adequate withdrawal time is prescribed. In other cases residues present in edible product are considered to be acceptable with a view to human health. From the perspective of HACCP, the critical control point is the farmer or the veterinarian, who are responsible for obeying any legal obligations related to the use of the drug or additive.

Carry-over of drugs or additives from one medicated feed batch to the next non-medicated one during either manufacturing, transport or even at the farm can - however - occur. The critical control points for this chain of events are both in the feed mill and on the farm. Systems like GMP for feed production and GAP at the farm should ensure that adequate precautions should be taken. The reported incidence of coccidiostat residues in eggs in the EU in 2003 (SANCO/2810/2004) does however indicate that good control has not yet been achieved. The carry-over of drugs to eggs is well established (Kan, 2007), but unfortunately the results obtained in laying hen experiments have little predictive value for carry-over in dairy cows (Kan et al. 2001).

Risk management - two main actions should be taken: Firstly, adherence to adequate administration and prescribed withdrawal times. Secondly, due attention - when producing and using medicated feeds - to prevent carry-over both in the feed mill and at the farm.

Acrylamide - Acrylamide is rapidly and extensively absorbed from the gastrointestinal tract and is widely distributed to the tissues (JECFA, 2006). Carry-over studies with farm animals give the following results. Laying hens excreted via their manure more than $99 \%$ the radiolabel of 14C labelled acrylamide within 48 hours. Approximately 0.5 $\%$ of the label occurred in the eggs (Blumenthal et al., 1995). Similarly, Kienzle et al. (2005) recovered approximately 0.3 $\%$ of the daily dose of acrylamide, from the eggs of quail. No detectable amounts were found in liver but muscle tissue 
did contain detectable but low residues. Overall, only $6 \%$ of the acrylamide could be recovered intact (Kienzle et al., 2005). This indicates extensive metabolism or irreversible binding e.g. to protein. A cow was dosed with $1.5 \mathrm{~g}$ acrylamide in a capsule daily for 10 days after the morning milking. Acrylamide levels in the milk were consistently much higher in the evening milk, than in the morning milk indicating rapid degradation or excretion. The average carry-over rate to the evening milk was $0.23 \%$ and to the morning milk $0.01 \%$. A mean half-life of 2.8 hours could be calculated from the results. Based on the results, an average expected level in milk of $0.2 \mu \mathrm{g} / \mathrm{kg}$ was calculated (Pabst et al., 2005).

Chlorinated paraffins - Very little data on both carryover studies and data on levels of chlorinated paraffins in human food exist. The difficulties of analysing chlorinated paraffins due to the extreme complexity of the mixtures that are used is responsible for that fact (Who, 1996). Sheep, grazing near a plant producing chlorinated paraffins, have been found to contain residues in liver, fat and kidney. However, the highest levels were found in their fleece, which suggests aerial transport to be of importance (Who, 1996). The carry-over study with broilers by Ueberschär \& Matthes (2004) showed clear dose-response relationships in different organs. Less than $5 \%$ of the administered dose (during 31 days) could be recovered from the animals (Ueberschär \& Matthes, 2004), most of the intake being either metabolized or excreted.

Mineral hydrocarbons - The 1997 report of the EU indicated that only very limiteddata were available on the likely exposure of humans to mineral hydrocarbons from its use in foods (Food, 1997). Mineral oil hydrocarbons are deposited in fatty tissues of farm animals, if present in their feed (Grob et al., 2001). These authors found $n$ alkanes with chain lengths from 10 to about $40 \mathrm{C}$-atoms in both feed and products of animal origin. A balance calculation for laying hens indicates a transfer of about 2 $\%$ of these alkanes to eggs.

Polycyclic aromatic hydrocarbons (PAHs) - In food, $\mathrm{PAH}$ is primarily formed during processing and domestic food preparation procedures, such as smoking, drying, roasting, baking, frying or grilling (Food, 1997). Carry-over of PAH from contaminated feedstuffs to animal products has not been addressed widely. Generally PAH metabolism and excretion in experimental animals is found to be rapid (Food, 2002). Lutz et al. (2006) gave PAHs bound to soil through a rumen canula to three cows for 28 days. Levels of the parent compounds in milk did not increase during exposure. Some hydroxylated metabolites however, showed higher levels in milk. Grova et al., (2006) reported similar results from a study with dairy goats given the PAHs in oil. These results do not explain why in milk samples from different regions both in Finland (Hietaniemi, 1996) and the USA (Schaum at al., 2003) differences in PAH content could be found. (Ciganek \& Neca, 2006) reported PAH to be found in almost all porcine and bovine tissues and organs. Feed intake, respiration of contaminated air and percutaneous intake are considered to be of importance in the exposure of animals by these authors (Ciganek \& Neca, 2006). Whether these results can or will be duplicated in other areas is not (yet) known.

Risk management - the critical control points in substances present in the different feedstuffs, are both in the production of plants and during their processing. Good agricultural or management practices will help in identifying any critical steps during that phase of production. Unfortunately not many or sometimes no options to decontaminate exist, once contamination has occurred (Kan, 1994). Most attention should be given - as already indicated - to fat containing feedstuffs as most contaminants discussed are well soluble in fats and oils. Sampling should preferably be executed on the raw materials, as they arrive before any mixing has been accomplished. After mixing, tracking and tracing of any contamination source will become much more difficult. Also checks in foods to ascertain that contaminant levels are below acceptable levels, should preferably be done on a fat rich product or the fatty portion of a product.

Exposure of animals due to environmental contamination of soil or air is very hard to control. The existence of a contamination can sometimes be proven, but hardly no practical means exist to reduce exposure of animals under those conditions. In extreme cases, removal and destruction of the animals or (part of) their products, is the only option to prevent humans for unwanted exposure.

Conclusions - Carry-over of toxic substances from feed to food is influenced by absorption, metabolism and excretion of the compound. Absorption and excretion occur both in the intestine and in other tissues. Measuring in feed and food only, obscures the relative contributions of the different processes in the animal and does not reveal the possibilities to intervene in these processes. The following actions are possible in general terms: 1) Prevention of exposure either through feed or from the environment; 2) Application of a withdrawal time; 3) Use of adsorbents to bind toxic substances in the feed; 4) Manipulation of animal physiology to enhance metabolism or excretion of contaminants from the animal.

Prevention of exposure is by far the preferred risk 
management tool. Known contaminants from known sources can be handled effectively in this way. The absence of simple and cheap analytical methods to check for the presence of all possible contaminants in all feedstuffs at the feed mill level causes unfortunately this system to fail from time to time as the dioxin problems in 2006 in animal fat in Belgium and the Netherlands have shown.

Withdrawal times should be followed if prescribed legally and may in some instances provide a solution. In case of milk and eggs - being produced on a daily basis the animal products are most likely to show increased residue levels during (prolonged) exposure. Use of adsorbents has been tested extensively both for organochlorine compounds and mycotoxins.

The results for organochlorine compounds have not been promising (Kan, 1994). Diaz \& Smith (2005) pointed out that for mycotoxins there are some promising products, but certainly no general solutions.

Mycotoxin control is quite hard to be executed as weather conditions play a pivotal role in fungal growth and mycotoxin formation. Absorbents added to the feed may sometimes alleviate the problem.

Environmental contamination is still a problem for a control and risk management system. Contaminations are generally dealt by on a case by case basis. Risk assessment for consumers plays an important role there, as well as economic and feasibility aspects. The absence of simple and cheap analytical methods for detecting most contaminants precludes extensive screening as a tool for risk management.

The information on possible intervention strategies as a risk management tool to be used in a HACCP approach is often lacking. Development of quality systems requires this knowledge and will become another "pulling" force in setting the research agenda.

Risk communication - Winter \& Francis (1997) wrote in a status summary more than ten years ago: "Common methods for communicating food chemical risk information have been characterized as one-way and technocratic, in which government leaders, industry, or regulatory agencies provide risk assessment and risk information with the aim that the public accept the risk messages being conveyed and act accordingly". They further stated that the risk management model of the EPA for pesticides had a component of limited risk balancing next to reasonable certainty of no harm. This illustrates the technocratic approach dominating the views in the twentieth century, before the internet became the main source of information about food safety for many (concerned) people in the western world. Food scandals relating to chemical residues such as the Belgian dioxin crisis in 1999, had-nevertheless - only a limited influence of the perception of Belgian consumers with regard to poultry and pig meat (Verbeke, 2001). However, the relative position of beef meat improved as opposed to earlier measurements. The large amounts of negative press on poultry and pork, to a large extent not controlled by government or industry, thus had its influence on public perception, whether right or wrong. Shaw (2003) interviewed 17 experts and 32 consumers in the UK about the public understanding of food risks and the difference between experts and lay views in this respect. Some relevant points from this study are the poor public understanding of food hygiene reported by the experts. Also, the informal word of mouth had an important role amongst consumers in both negative and positive information about food issues.

McCarthy \& Henson (2005) interviewed over 500 Irish consumers about perceived risks in relation to beef consumption. They discriminate between three main groups: "Sceptics", for whom the financial risk of money wasted, due to products not meeting expectations, was of most concern. "Concerned consumers" for whom next to financial risk, health and psychological risks were equally important and "Optimists" who are not overly concerned about safety and health risks. Overall, the safety risk of beef (especially BSE related) was perceived as quite low. They further state, that for the sceptics quality assurance programs may have a limited impact only. Rather, those sceptics were considered to respond more to a combination of quality label information and advice at the point of purchase (such as the independent butcher!). In a follow up study (McCarthy et al., 2007) with over 140 experts and over 1000 consumers, they have tried to identify different segments of the population according to their food safety knowledge. They note in their introduction:" In certain circumstances, other factors such as tradition, habit, pleasure or financial constraints, may be more salient features of decision-making other than risk". Their results show that overall, technological risks including those of pesticide residues rank second in the list of potential food risks after microbial risks. They could identify four segments in their population according to knowledge levels; "At-Risk", "Food Safety Conscious", "Food Science Knowledge Deficient" and "Informed". The At-Risk segment accounted for $13 \%$ of the population and is clearly deficient in knowledge and might benefit from further education. However, this segment is unlikely to read broadsheet newspapers or to have completed any sort of home economics course. Thus, the chances for their further education are slim. The members of the other three segments 
are rather well informed about food safety issues (especially the microbial issues), but do not always adhere to - what are considered to be - best practices. Thus, understanding why best practices are not always adhered to, is essential before major improvements can be expected.

Yen et al. (2006) analysed data from a survey with over 4400 respondents spread around the USA with respect to awareness and perceived risk of pesticide and antibiotic residues in food. Awareness of one of the two residue problems was associated with a perceived lower risk from the other problem. Perceived risk from pesticide residues was lower with more adults in the household. The risk perception was different between the groups of different socioeconomic origin as can be expected, but also between groups of different racial origin.

In conclusion, many facts and circumstances have their influence on perceived risks of pesticides (and contaminants). Winter \& Francis (1997) list a number of them: involuntary exposure (as happens with residues in food) is on the top of their list but lack of trust in responsible institutions is also mentioned. This lack of trust has certainly not diminished over the past years, as more consumer groups and concerned consumers display their concerns about the reliability of official data on many places both in the media and on the internet. The scientific community and national and international authorities have not been able to increase the trust of consumers regarding food safety in recent years. Partly, this is due to the fact that it is quite easy to demonstrate an adverse effect of a certain substance, but very hard or nearly impossible the absence of an adverse effect in real life situations. Thus question marks about food safety will remain and can not be denied, whatever unlikely the occurrence of any adverse effect.

Recent experiments - The successes and pitfalls in carry-over studies with toxic substances in farm animals will be further illustrated with some results from recent - as yet unpublished - studies.

Laying hen study - The first study (Hoogenboom et al. unpublished, 2006) tested whether binders added to the diet of laying hens would influence absorption of dioxins, PAH (polycyclic aromatic hydrocarbons) or heavy metals present in contaminated soil if this soil was added to the diet of laying hens. In short: Five groups of 10 laying hens were kept in cages and had free access to one of five feeds, i.e. $20 \%$ sand (blank = A), $20 \%$ soil (feed B), $20 \%$ soil and $2 \%$ binder A (Feed C), 20\% soil and 0.5\% Binder B (Feed D), or $20 \%$ soil and $2 \%$ Binder B (Feed E). Previous research had shown (van der Meulen et al., 2008), that laying hens are able to adapt their feed intake to a dilution rate of $30 \%$ with sand without any problem. Thus a normal egg production on these feeds was anticipated. The study was planned to last 112 days. However, after about 50 days, egg production started (rather suddenly) to decline in groups C, D and E and about two weeks later also in group B. Thus, it was decided to terminate the study. At first, we had no explanation for the decreased egg laying. Closer examination of the hens by veterinary autopsy showed a severe decalcification of their skeleton as well as bone fractures. Many animals showed intestinal disturbances. The ovaries in most animals were not containing any developing yolks, consistent with the cessation of egg-laying. Mineral analysis of the feed and faeces revealed no or minor differences between feeds for $\mathrm{Ca}, \mathrm{P}, \mathrm{Cu}, \mathrm{Zn}, \mathrm{Na}, \mathrm{K}$ and $\mathrm{Mg}$ contents. However an almost 10 fold difference in Fe levels was observed between feed and faeces of group A and those from groups B-E (feed A $400 \mathrm{mg} / \mathrm{kg}$, feeds B-E > $5000 \mathrm{mg} / \mathrm{kg}$ ). As expected, the contaminated soil also contained quite high $(20 \mathrm{~g} / \mathrm{kg})$ levels of Fe. This large iron supply probably bound much of the $\mathrm{P}$ present in the diet and thus caused the rachitic type problems observed.

The analytical data on the eggs showed that the pharmacokinetic behaviour of the dioxins nicely followed the model described earlier by van Eijkeren et al. (2006). The binders added to the diet did not influence the dioxin levels in the eggs. Although elevated levels of both heavy metals and PAH were present in the feed, their levels in eggs were not elevated. For heavy metals this is in line with earlier results reported in the literature (Kan, 2005). The absence of carry-over of PAH is in line with the results of a carry-over trial in dairy cows (Hoogenboom et al unpublished results, 2003). However in both instances we only looked for the parent PAH compounds, so it might be possible that (hydroxylated) metabolites can nevertheless be found in the animal product.

Growing pig study - We (Hattink et al., 2007; unpublished results) fed diets with levels of 1 and $10 \mathrm{mg} / \mathrm{kg}$ cadmium in the form of cadmium chloride or cadmiumcystein (mimicking a protein bound form of cadmium) for up to twelve weeks to growing male pigs starting at a weight of about $20 \mathrm{~kg}$. Some groups received a contaminated diet for a limited period and a control diets afterwards. Ea ch treatment group consisted of three pigs. At different time points, animals were slaughtered and samples taken from all major organs including meat, liver, kidney, testes and bone.

The animals grew well but there was a slight growth depression in both $10 \mathrm{mg} / \mathrm{kg}$ groups after 12 week. The $\mathrm{Cd}$ analyses in the different tissues revealed no rise in muscle 
Cd levels as expected. The levels in liver in kidney and liver increased most (Figures 2 and 3 ) as expected and no differences between the two $\mathrm{Cd}$ sources could be detected in this respect. Less than $0.1 \%$ of the total dose was retained in liver or kidney.

We also measured Cd levels in liver and kidneys after the pigs had received contaminated diets for 3 weeks and an uncontaminated control diet for a further 9 weeks. This revealed that the absolute amount of $\mathrm{Cd}$ remained similar during the 9 weeks depletion period, indicating that the concentration in the organs only dropped due to growth of the organs and not due to a washout from them.

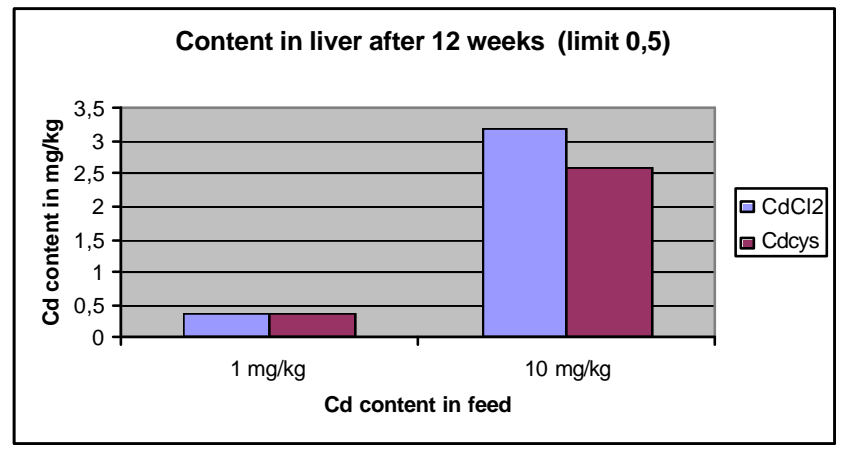

Figure 2 - Cadmium levels in liver after 12 weeks of exposure.

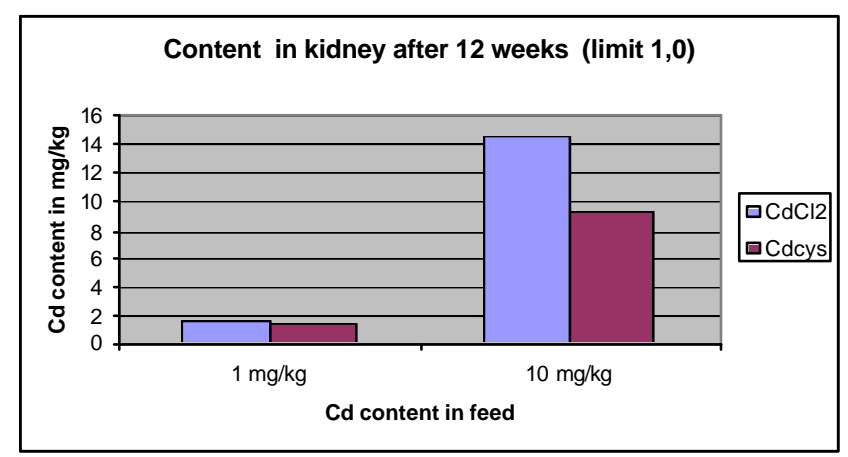

Figure 3 - Cadmium levels in kidney after 12 weeks of exposure.

\section{Conclusions}

Carry-over of toxic substances from feed to food does occur and can in some instances be prevented by Good Agricultural or Manufacturing Practices. One a food has been contaminated removal of the contaminated might be technically feasible but seldom economically. Incidents will remain to occur as total control on all substances under all circumstances is an illusion.

\section{Literature Cited}

BARBOSA, J.; CRUZ, C.; MARTINS, J. et al. Food poisoning by clenbuterol in Portugal. Food Additives and Contaminants, v.22, p.563-566, 2005.

BLUMENTHAL, G.M.; ABDEL-RAHMAN, A.A.; WILMARTH, K.R. et al. Toxicokinetics of a single $50 \mathrm{mg} / \mathrm{kg}$ oral dose of [2,3-14C]acrylamide in White Leghorn hens. Fundamental and Applied Toxicology, v.27, p.149-153, 1995.

CIGANEK, M.; NECA, J. Polycyclic aromatic hydrocarbons in porcine and bovine organs and tissues. Veterinarni Medicina Czech, v.51, p.239-247, 2006

DÄNICKE, S. Prevention and control of mycotoxins in the poultry production chain: a European view. World's Poultry Science Association Journal, v.58, p.451-474, 2002.

DÄNICKE， S.;VALENTA， H.; UEBERSCHÄR, K. H. Risikofaktoren für die Fusariumtoxinbildung in Futtermitteln und Vermeidungsstrategien bei der Futtermittelerzeugung und Fütterung; Risikoabschätzung und Vermeidungsstrategien bei der Fütterung. Landbauforschung Volkenrode, Sonderheft 216 , p.35-138, 2000.

DIAZ, D.E.; SMITH, T.K. Mycotoxin sequestering agents: Practical tools for the neutralisation of mycotoxins. In: DIAZ, E.D. (Ed.) The mycotoxin blue book. Nottingham: Nottingham University Press, 2005. p.323-339.

FOOD, Scientific Committee On. Opinion on mineral and synthetic hydrocarbons. In: Reports of the Scientific Committee for Food. Ed. EU COMMISSION. Luxemburg, EU. Report 37, 1997, 39p.

FOOD, Scientific Committee On. Opinion of the Scientific Committee on Food on the risks to human health of polycyclic aromatic hydrocarbons in food. Ed. EU. COMMISSION. Brussels, EU. Report SCF/CS/CNTM/PAH/29 Final 2002, 2002, 84p

GALVANO, F.; PIVA, A.;RITIENI, A., et al. Dietary strategies to counteract the effects of mycotoxins: a review. Journal of Food Protection, v.64, p.120-131, 2001.

GEERTSMA, M.F.; NOUWS, J.F.M.; GRONDEL, J.L. et al. Residues of sulphadimidine and its metabolites in eggs following oral sulphadimidine medication of hens. Veterinary Quarterly, v.9, p.67-75, 1987.

GROB, K.; VASS, M.; BIEDERMANN, M. et al. Contamination of animal feed and food from animal origin with mineral oil hydrocarbons. Food Additives and Contaminants, v.18, p.1$10,2001$.

GROVA, N.; RYCHEN, G.; MONTEAU, F., et al. Effect of oral exposure to polycyclic hydrocarbons on goat's milk contamination. Agronomy for Sustainable Development v.26, p.195-199, 2006.

HIETANIEMI, V. Levels and trends of PCBs, organochlorine pesticide residues and carcinogenic or mutagenic $\mathrm{PAH}$ compounds in Finnish and imported foods and diets. In: KUMPULAINEN, J.T. (Ed.) Natural antioxidants and food quality in atherosclerosis and cancer prevention. UK, Royal Society of Chemistry. 1996 p.432-436

HOOGENBOOM, L.A.P.; KAN, C.A.; BOVEE, T.F.H. et al. Residues of dioxins and PCBs in fat of growing pigs and broilers fed contaminated feed. Chemosphere, v.57, p.35-42, 2004.

HOOGENBOOM, L. A. P.; ZEILMAKER, M. J.; KAN, C. A., et al. Kaolinic clay derived dioxins in potato by-products. In: DIOXINS 2005. Toronto. 2005.

JECFA Evaluation of certain food contaminants. In WHO Technical Report Series. Ed. FAO/WHO Expert Committee On Food Additives. Geneva, WHO. 2006 Report 930. 107p.

KAN, C.A. Short-term balance studies of some organochlorine pesticides in poultry. In: International conference on in vivo aspects of biotransformation and toxicity of industrial and environmental xenobiotics. Ed I. GUT. 
Prague. 1977 paper 47.

KAN, C.A. Factors affecting absorption of harmful substances from the digestive tract of poultry and their level in poultry products. World's Poultry Science Journal, v.50, p.39-53, 1994.

KAN, C.A.; HAJEE, C.A.J.; Van RHIJN, J.A. Differences in transfer of nicarbazin, meticlorpindol and ivermectin from feed to milk. Journal of Dairy Science, v.84, suppl.1, p.115, 2001.

KAN, C.A. Chemical residues. In: MEAD, G.C. (Ed.)Poultry meat processing and quality. Cambridge: Woodhead Publishing Ltda., 2004. p.258-282.

$\mathrm{KAN}, \mathrm{C}$. A. Chemical residues in poultry and eggs produced in freerange or organic systems. In: EUROPEAN SYMPOSIUM ON THE QUALITY OF POULTRY MEAT, 17., EUROPEAN SYMPOSIUM ON THE QUALITY OF EGGS AND EGG PRODUCTS, 6., 2005, Doorwerth.Proceedings... Doorwerth: WPSA, 2005. p.28-36.

KAN, C. A. Contaminants in eggs: effects of feed and environment In: EUROPEAN SYMPOSIUM ON THE QUALITY OF POULTRY MEAT, 17., EUROPEAN SYMPOSIUM ON THE QUALITY OF EGGS AND EGG PRODUCTS, 12., 2007, Prague. Proceedings... Prague, WPSA. 2007 p. 69-72.

KAN, C.A.; MEIJER, G.A.L. The risk of contamination of food with toxic substances present in animal feed. Animal Feed Science and Technology, v.133, p.84-108, 2007.

KIENZLE, E.; RANZ, D.; THIELEN, C. et al. Carry over (transfer) of feed-borne acrylamide into eggs, muscle, serum, and faeces a pilot study with Japanese quails. Journal of Animal Physiology and Animal Nutrition, v.89, p.79-84, 2005.

KREUZER, W.; BUNZL, K.; KRACKE, W. Zum Übergang von Cadmium aus dem Futter in Nieren, Lebern und Muskulatur von Slachtrindern. Fleischwirtschaft, v.61, p.1886-1894, 1981.

LUTZ, S.; FEIDT, C.; MONTEAU, F., et al. Effect of exposure to soil-bound polycyclic aromatic hydrocarbons on milk contaminations of parent compounds and their monohydroxylated metabolites. Journal of Agricultural and Food Chemistry, v.54, p.263-268, 2006.

MCCARTHY, M.; BRENNAN, M.; KELLY, A.L. et al. Who is at risk and what do they know? Segmenting a population on their food safety knowledge. Food Quality and Preference,v.18, p.205-217, 2007.

MCCARTHY, M.; HENSON, S. Perceived risk and risk reduction strategies in the choice of beef by Irish consumers. Food Quality and Preference, v.16, p.435-445, 2005.
PABST, K.; MATHAR, W.; PALAVINSKAS, R. et al. Acrylamideoccurrence in mixed concentrate feed for dairy cows and carryover into milk. Food Additives \& Contaminants, v.22, p.210-213, 2005 .

SCHAUM, J.; SCHUDA, L.; WU, C. et al. A national survey of persistent, bioaccumulative, and toxic (PBT) pollutants in the United States milk supply. Journal of Exposure Analysis and Environmental Epidemiology, v.13, p.177-186, 2003.

SHAW, A. Public understanding of food risks. FoodInfo Online Features, p.12, 2003.

UEBERSCHÄR, K. H.; MATTHES, S. Dose-response feeding study of chlorinated paraffins in broiler chickens: effects on growth rate and tissue distribution. Food Additives and Contaminants, v. 21 , p.943-948, 2004.

VAN DER MEULEN, J.; KWAKERNAAK, C.; KAN, C. A. Sand intake by laying hens and its effect on egg production parameters. Journal of Animal Physiology and Animal Nutrition, v.92, p.426-431, 2008.

VAN EIJKEREN, J.C.H.; ZEILMAKER, M.J.; KAN, C.A. et al. A toxicokinetic model for the carry-over of dioxins and PCBs from feed and soil to eggs. Food Additives and Contaminants, v.23, p.509-517, 2006.

VERBEKE, W. Beliefs, attitude and behaviour towards fresh meat revisited after the Belgian dioxin crisis. Food Quality and Preference, v.12, p.489-498, 2001.

VREMAN, K.; van der VEEN, N.G.; van der MOLEN, E.J. et al. Transfer of cadmium, lead, mercury and arsenic from feed into milk and various tissues: chemical and pathological data. Netherlands Journal of Agricultural Science,v.34, p.129$144,1986$.

WHO Polybrominated biphenyls, Environmental Health Criteria volume 152, World Health Organization Geneva, 1994, 577p.

WHO Chlorinated paraffins. Environmental Health Criteria volume 181, World Health Organization Geneva, 1996, 50p.

WINTER, C.K.; FRANCIS, F.J. Assessing, managing and communicating chemical food risks. Food Technology, v.51, p.85-92, 1997.

YEN, S.T.; JENSEN, K.L.; LIN, C., T.J. Awareness and perceived risk of pesticide and antibiotic residues in food: Socioeconomic variations among United States' consumers. Food Protection Trends, v.26, p.645-661, 2006. 